\title{
Effect of Biodiesel Blends on Diesel Particulate Filter Performance
}

\author{
Aaron Williams, Robert L. McCormick, R. Robert Hayes, John Ireland \\ National Renewable Energy Laboratory
}

Howard L. Fang

Cummins, Inc.

Copyright $@ 2006$ Society of Automotive Engineers, Inc.

\begin{abstract}
Tests of ultra-low sulfur diesel blended with soy-biodiesel at $5 \%$ and $20 \%$ were conducted using a 2002 model year Cummins ISB engine (with exhaust gas recirculation) that had been retrofitted with a passively regenerated catalyzed diesel particulate filter (DPF). Results show that on average, the DPF balance point temperature (BPT) is $45^{\circ} \mathrm{C}$ and $112^{\circ} \mathrm{C}$ lower for B20 blends and neat biodiesel, respectively, than for 2007 certification diesel fuel. Biodiesel causes a measurable increase in regeneration rate at a fixed steady-state condition, even at the $5 \%$ blending level. The data show no significant differences in $\mathrm{NO}_{x}$ emissions for these fuels at the steady-state regeneration conditions, suggesting that differences in soot reactivity are responsible for the observed differences in BPT and regeneration rate. Soot from the various fuels was characterized by determining the fuel and lubricant fractions of the soluble organic fraction, elemental and organic carbon content, amorphous carbon/graphitic carbon ratio by Raman spectroscopy, carbon/oxygen ratio by energy dispersive $x$-ray analysis, and reactivity in oxygen by TGA. Results indicate a much more disordered soot structure, containing higher levels of oxygen as biodiesel is blended into the diesel fuel. The soot produced from biodiesel and blends is much more reactive in oxygen than diesel soot. It is concluded that the lower balance point temperature and higher DPF regeneration rates for biodiesel containing fuels are observed because the soot generated from these blends is more reactive.
\end{abstract}

\section{INTRODUCTION}

Biodiesel is a renewable fuel derived from vegetable oil, animal fat, or waste cooking oil and consists of the methyl esters of fatty acids. It is typically used as a diesel blending component at levels of 20 volume percent or lower. A resource assessment indicates that biodiesel has the potential to displace $5 \%$ or more of petroleum diesel over the next decade [1]. A life cycle analysis indicates that biodiesel is a highly renewable fuel, and that use of B20 results in a 19\% reduction in life cycle petroleum consumption [2]. The United States Environmental Protection Agency (EPA) has reviewed biodiesel emissions data for heavy-duty engines published up through about 2000 [3]. For transient engine dynamometer testing, the average emission changes for B20 versus petroleum diesel were $+2.0 \%$ for $\mathrm{NO}_{x},-10.1 \%$ for PM, $-11.0 \%$ for carbon monoxide (CO), and $-21.1 \%$ for total hydrocarbons (THC). However, closer scrutiny of the available data suggests that increasing $\mathrm{NO}_{\mathrm{x}}$ is not necessarily a general phenomenon for biodiesel at the $\mathrm{B} 20$ level, and that $\mathrm{NO}_{\mathrm{x}}$ emissions depend upon engine duty cycle or mode as well as engine technology [4]. More recently data were published reporting the testing of two newer engines equipped with EGR and meeting the 2004 emission standards, with B20 vs. ultra-low sulfur diesel (ULSD) fuel. This study found, on average, a $25 \%$ reduction in PM emissions for B20 [5], but NOx increased by nearly 4 $\%$.

In 2007, new emission standards for on-road heavy-duty diesel engines will begin to phase in. Most relevant to this work, beginning with the 2007 model year the particulate matter emission standard will be lowered from $0.1 \mathrm{~g} / \mathrm{bhp}-\mathrm{h}$ to $0.01 \mathrm{~g} / \mathrm{bhp}-\mathrm{h}$. This lowering of PM emissions by a factor of 10 is enabled by the introduction of diesel fuel containing a maximum of $15 \mathrm{ppm}$ sulfur (ULSD) beginning in June of 2006 and the use of diesel particulate filters. In a DPF, soot particles are trapped on a filter. In catalyzed DPF systems such as that tested here, the soot is then burned by reaction with $\mathrm{NO}_{2}$. The role of $\mathrm{NO}_{2}$ as an oxidizer is critical to catalyzed DPF performance and DPFs typically contain a precious metal catalyst upstream of the ceramic filter, where $\mathrm{NO}$ is converted to $\mathrm{NO}_{2}$. This $\mathrm{NO}_{2}$ is a more aggressive oxidizer of soot at low temperatures than is oxygen, and thus can control the soot oxidation rate. Thus, a small increase in $\mathrm{NO}_{x}$ emissions (mainly $\mathrm{NO}$ ) observed for B20 during transient testing could have significant consequences for the performance of B20 with DPFs. 
Some published information is available on the performance of DPFs with biodiesel and biodiesel blends. Testing of B20 and several other fuels with various aftertreatment and engine configurations [6] has been reported. The use of a catalyzed DPF produced a factor of 10 reduction in PM emissions relative to the base case. No PM emission advantage was observed for B20 with a DPF installed. No engine-out emissions were reported for B20 in this study. Additionally, 2007 compliant procedures for PM emission measurement do not appear to have been used. However, Boehman and coworkers [7] have recently shown that blending of $20 \%$ biodiesel into diesel fuel can significantly lower balance point temperature (BPT). They present results showing that this is not caused by increased availability of $\mathrm{NO}_{2}$, but by inherent differences in soot reactivity for different fuels. This was confirmed by thermogravimetric analysis wherein soot produced in an engine from different fuels was burned under identical conditions. Soot characterization by electron microscopy suggested that the cause of this increased reactivity is a more highly disordered soot nanostructure for B20 blends such that the soot is more reactive or reactive at lower temperatures. More recent results presented by Boehman [8] suggest that changes in nanostructure are not the cause of increased reactivity, but rather the introduction of highly reactive surface oxygen sites when the soot is produced from B20.

Here we examine the impact of biodiesel and biodiesel blends on balance point temperature, filter regeneration rate, and transient emissions using a modern (2004 compliant) engine and state of the art (2007/2010 compliant) emissions measurement system.

\section{EXPERIMENTAL SETUP}

The test setup consisted of a 2002 model year $5.9 \mathrm{~L} 300$ hp Cummins ISB, equipped with a diesel particle filter (DPF). Properties of the test engine are shown in Table 1. The engine employs cooled high-pressure EGR, a variable geometry turbocharger, electronic control, and high-pressure common rail direct fuel injection, designed and calibrated to meet the 2004 U.S. heavy-duty emissions standards.

The DPF is a $12 \mathrm{~L}$ catalyzed diesel particle filter employing Catalyzed Continuously Regenerating Technology (CCRT ${ }^{\mathrm{TM}}$ ) provided by Johnson Matthey, a passively regenerated system. The CCRT ${ }^{\mathrm{TM}}$ filter is a diesel oxidation catalyst followed by a wall-flow catalyzed soot filter. It is used in applications with average exhaust temperatures as low as $200^{\circ} \mathrm{C}-250^{\circ} \mathrm{C}$. The DPF is mounted $152 \mathrm{~cm}$ from the engine turbo flange outlet. The DPF was instrumented for inlet and outlet temperatures and pressures as well as differential pressure. Temperatures were measured with K-type thermocouples mounted $8 \mathrm{~cm}$ from the face of the precatalyst on the inlet side and $8 \mathrm{~cm}$ from the face of the DPF on the outlet side. Inlet and outlet pressures as well as differential pressure were measured from the same location. The overall setup and relative location of all instrumentation is illustrated in Figure 1. In addition, engine and emissions sampling systems were instrumented for measurement of all other critical temperatures and pressures.

Table 1. Test engine specifications

\begin{tabular}{lc}
\hline & Cummins ISB \\
\hline Serial Number & 56993170 \\
Displacement, L & 5.9 \\
Cylinders & 6 \\
Rated Power, kW & 224 at $2500 \mathrm{rpm}$ \\
Rated Torque & $895 \mathrm{~N}-\mathrm{m}$ at $1600 \mathrm{rpm}$ \\
Bore $x$ Stroke & $10.2 \times 12 \mathrm{~cm}$ \\
Compression Ratio & $16.5: 1$ \\
Fuel System & Common Rail \\
Intake Restriction, $\mathrm{kPa}$ & 4.47 \\
Exhaust Backpressure, $\mathrm{kPa}$ & 7.95 \\
\hline
\end{tabular}

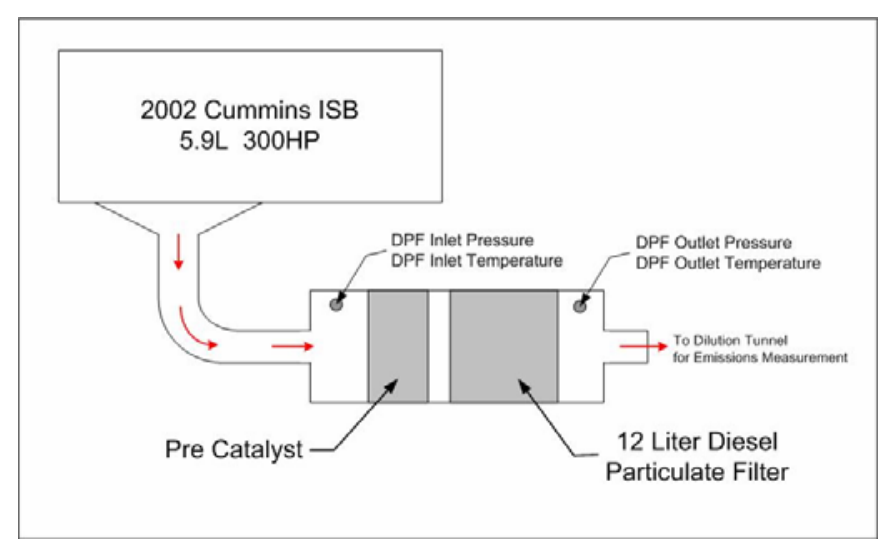

Figure 1. Experimental Setup

The engine was mounted to a DC electric engine dynamometer at NREL's Renewable Fuel and Lubricant (ReFUEL) laboratory. ReFUEL's engine dynamometer is part of a fully functional test cell capable of steady state or transient testing for emissions and fuel consumption. The ReFUEL emission measurement system is based on the full scale dilution method with Constant Volume Sampling (CVS) for mass flow measurement. Gaseous emissions, including $\mathrm{CO}_{2}, \mathrm{NO}_{\mathrm{x}}, \mathrm{THC}$ and $\mathrm{CO}$ are measured continuously. Particulate matter (PM) emissions are measured based on a gravimetric system, in which samples are collected onto $47 \mathrm{~mm}$ Teflon membrane filters and then weighed with a microbalance in a clean room environment.

Test fuels included 2007 certification diesel and various biodiesel blends made from a soy biodiesel feedstock. The soy biodiesel was $\mathrm{S} 15$ grade and met the requirements of ASTM D6751. Fuel properties for the 2007 certification ULSD and the neat biodiesel are listed in Table A-1 in the Appendix. 


\section{PROCEDURES AND RESULTS}

\section{ESTIMATION OF PARTICLE LOADING}

In addition to fuel effects, performance of the DPF could be affected by the level of particulate loading. Thus, experiments were conducted to understand how to repeatedly preload the DPF with the same amount of particulate, and how to quantify that amount. In all cases the 12 Liter DPF was loaded to approximately $1.5 \mathrm{~g} / \mathrm{L}$ to approximate typical in-use loading levels. However, the amount of time necessary to produce the total 18 grams of PM at the $2000 \mathrm{rpm} 20 \mathrm{ft}-\mathrm{lb}$ preload condition is different for each fuel. A series of experiments were conducted to determine the rate of PM production by the engine for each fuel at the preload condition. The results of these experiments were then used to determine the proper load period for all subsequent BPT and regeneration rate testing. In addition, a method of weighing the DPF before and after loading was developed to further confirm the total mass collection.

\section{Particulate Matter Rate Study}

Testing was conducted to determine the total output of PM from the engine when operating at the $2000 \mathrm{rpm} 20$ $\mathrm{ft}-\mathrm{lb}$ preload condition for a 340 minute period. Without the DPF installed, engine-out PM samples were collected every 20 minutes for the entire 340 minute duration. Samples were collected onto $47 \mathrm{~mm}$ Teflon membrane filters at a sample flow rate of $43 \mathrm{~L} / \mathrm{min}$ for 20 minutes each. The filters were then weighed to determine the total PM production from the engine. This test was conducted for 2007 certification diesel (2007 Cert), B20 and B100, the results of which are shown in Figure 2. Assuming that the DPF captures and stores all of the PM at the preload condition, total collection of 18 grams (1.5 $\mathrm{g} / \mathrm{L}$ ) would take 332, 314 and 239 minutes for B100, B20 and 2007 Cert respectively.

\section{DPF Loading by Weight}

The preload condition of the DPF was further confirmed by taking fully regenerated (clean) and loaded weights of the DPF. The DPF weighed $17.2 \mathrm{~kg}$ compared to the 18 grams of PM being collected, illustrating the degree of accuracy necessary. An electronic balance with a resolution of 0.1 grams was used. Initially the DPF was allowed to equilibrate in an environmental chamber for a minimum of 12 hours before weighing. Temperature and humidity were controlled to $20^{\circ} \mathrm{C}$ with a relative humidity of $47 \%$. When weighing the DPF during this 12 hour

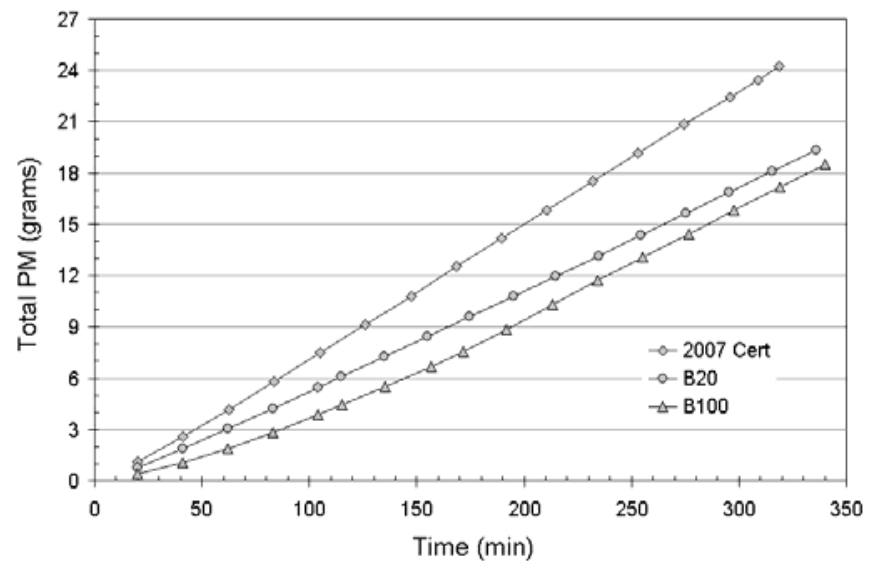

Figure 2. PM rate study results for B100, B20 and 2007 Certification Diesel

stabilization period, it was found that the DPF would immediately begin gaining weight in the relatively humid environment and eventually stabilize before the twelfth hour. The DPF appeared to absorb moisture even with substrate temperatures as high as $800^{\circ} \mathrm{F}$. Overall, the loaded DPF would gain as much as 13 grams of moisture before stabilizing. However, it was discovered that a clean DPF was more hygroscopic than a loaded DPF, gaining as much as 21 grams of moisture. Thus, accurate measurements of loaded mass could not be determined by taking the difference in clean and loaded DPF weights, each of which was taken after equilibration in a humid environment.

The second iteration of a weighing technique consisted of weighing the DPF in a dry room environment. In this case, with relative humidity controlled to below $20 \%$, the DPF still gained weight due to moisture, however, not as quickly. It was decided that the best technique for weighing was to remove the DPF as quickly as possible following engine operation and take immediate measurements in the dry room conditions. This technique yielded repeatable DPF loading measurements between 1.3 and $1.7 \mathrm{~g} / \mathrm{L}$ compared to the target $1.5 \mathrm{~g} / \mathrm{L}$ predicted by the PM rate studies.

\section{BALANCE POINT TEMPERATURE}

The balance point temperature is defined as the DPF inlet temperature at which the rate of particle oxidation approximately equals the rate of particle collection. At the balance point temperature during steady-state operation, the DPF should not experience a net gain or loss of particulate matter and consequently the differential pressure across the DPF should not change. A series of balance point temperature tests were conducted to compare the operation of a DPF on 2007 certification diesel, B100, and a B20 blend. The balance point temperature was determined with the following test sequence and is illustrated in Figure 3.

1. The DPF was completely regenerated by operating at near rated power $(2500 \mathrm{rpm}$ and $575 \mathrm{ft}$-lbs) for 120 minutes. 
2. The DPF was then preloaded with PM at 2000 rpm and $20 \mathrm{ft}-\mathrm{lbs}$ over the appropriate amount of time to achieve an approximate $1.5 \mathrm{~g} / \mathrm{L}$ loading of particulate matter on the DPF.

3. The preloaded DPF was then operated at 1700 rpm while torque was increased to achieve specified exhaust temperatures. The DPF pressure drop was monitored continuously to determine slope of the increase or decrease of the differential pressure across the DPF at a given inlet temperature.

4. This sequence was repeated for 2007 certification diesel, B100 and B20 fuels for determination of BPT at $1700 \mathrm{rpm}$.

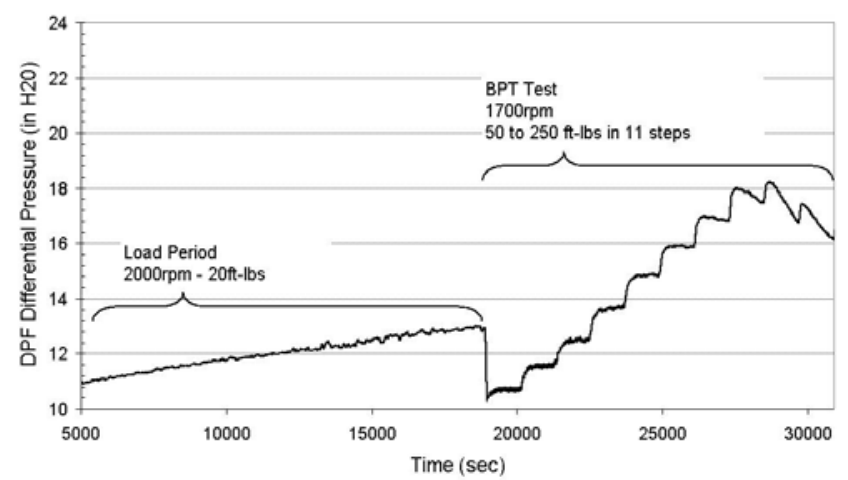

Figure 3. Balance point temperature test DPF differential pressure

The balance point temperature is determined by analyzing the slope of the differential pressure for each of the temperature steps. If the slope is positive (backpressure is increasing) then it is assumed that the DPF is collecting particulate matter. Once the slope becomes negative (backpressure is decreasing) that temperature is above the balance point temperature, as previously defined. The balance point temperature determination is made by plotting the slope of the differential pressure versus the DPF temperature for each of the steps. A linear curve fit is made between the two steps where differential pressure slope transitions from a positive to a negative value. The point where the curve fit crosses the Y-intercept is determined as the best estimate of the balance point temperature. In order to understand variability of the testing method, two repeats of the balance point temperature test were completed for 2007 certification diesel and B20, and three repeats for B100. In the case of 2007 certification fuel, additional torque steps were added in order to move sufficiently beyond the balance point temperature. Figure 4 shows the resulting balance point temperature windows for each of the fuels. On average, the balance point temperature is $45^{\circ} \mathrm{C}$ lower than 2007 certification diesel for B20 blends and $112^{\circ} \mathrm{C}$ lower for neat biodiesel.

\section{REGENERATION RATE}

The regeneration rate testing is similar to balance point temperature testing in that the DPF is fully regenerated and preloaded to approximately $1.5 \mathrm{~g} / \mathrm{L}$. However, rather than stepping through different torques at $1700 \mathrm{rpm}$, the engine moves directly to a single, relatively high torque (high temperature) operating point. This test method is illustrated in Figure 5. This method provides a potential advantage of comparing regeneration behavior between fuels at the same approximate DPF preload conditions (grams/Liter) and same high load steady-state operating point. This contrasts with the stepped BPT measurement method, which allows for different loading to occur during the "steps" following preload and prior to reaching the BPT.

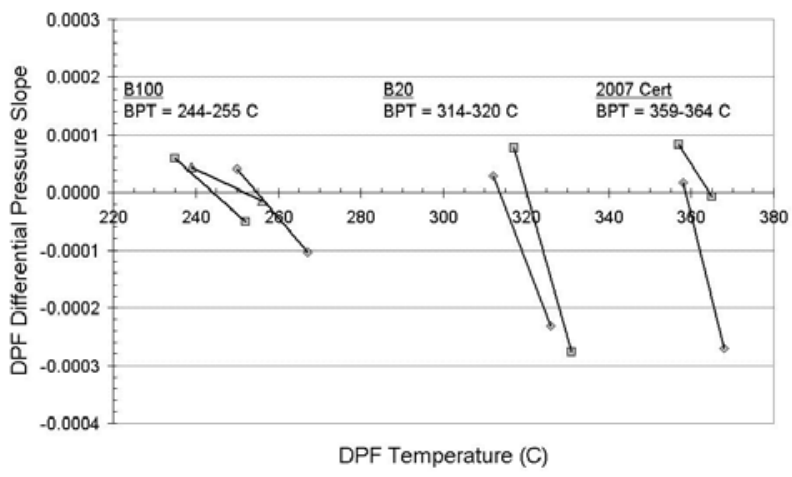

Figure 4. Balance point temperature test results for B100, B20 and 2007 Certification Diesel

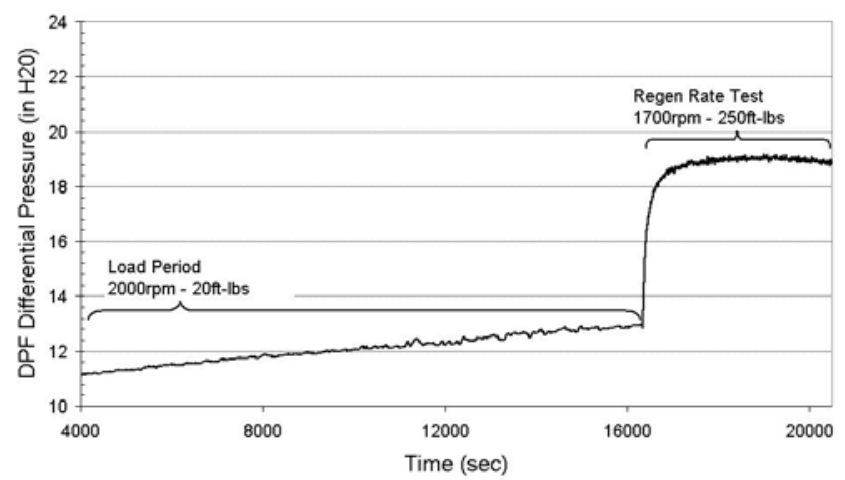

Figure 5. Regeneration rate test DPF differential pressure

Testing was conducted with 2007 certification diesel, B5 and B20 with two repeats for each fuel. Once the DPF had been preloaded the engine was then operated at the higher temperature point (1700 rpm and $250 \mathrm{ft}$-lbs) for 60 minutes. This allowed enough time for DPF temperature to stabilize. In each case, the DPF temperature at the active regeneration point stabilized between $348^{\circ} \mathrm{C}$ and $357^{\circ} \mathrm{C}$. In general, DPF inlet temperatures were lower with higher blend ratios of biodiesel. DPF differential pressures also varied from test to test, either as a consequence of the slight temperature differences or relative differences in the amount of particle loading. At the stabilized regeneration point, DPF differential pressures ranged between $48.3 \mathrm{~cm}$ of $\mathrm{H}_{2} \mathrm{O}$ and $52.1 \mathrm{~cm}$ of $\mathrm{H}_{2} \mathrm{O}$. 
Results for regeneration rates are shown in Figure 6. This plot shows the normalized DPF differential pressure for the final 15 minutes of steady state operation at the active regeneration point. DPF differential pressures are normalized to show relative differences in performance for each of the fuels. As the plot shows, the differential pressure slope for 2007 certification fuel is slightly positive for repeated runs at $1700 \mathrm{rpm}, 250 \mathrm{ft}-\mathrm{lb}$ operating condition with temperatures around $354^{\circ} \mathrm{C}$. This is consistent with previous testing that showed a balance point temperature somewhere between $359^{\circ} \mathrm{C}$ and $364^{\circ} \mathrm{C}$ for this fuel. The plot also illustrates that both biodiesel blends at the B5 and B20 level show measurable decreases in DPF differential pressure at the same operating condition with similar amounts of DPF preloading. The slope of the differential pressure decrease increases with biodiesel content. These test results show that when fueled with biodiesel blends, PM appears to measurably oxidize more quickly than when fueled with certification diesel fuel (even down to the B5 level). Increased levels of biodiesel in the fuel appear to increase the rate of DPF regeneration at a given engine operating condition.

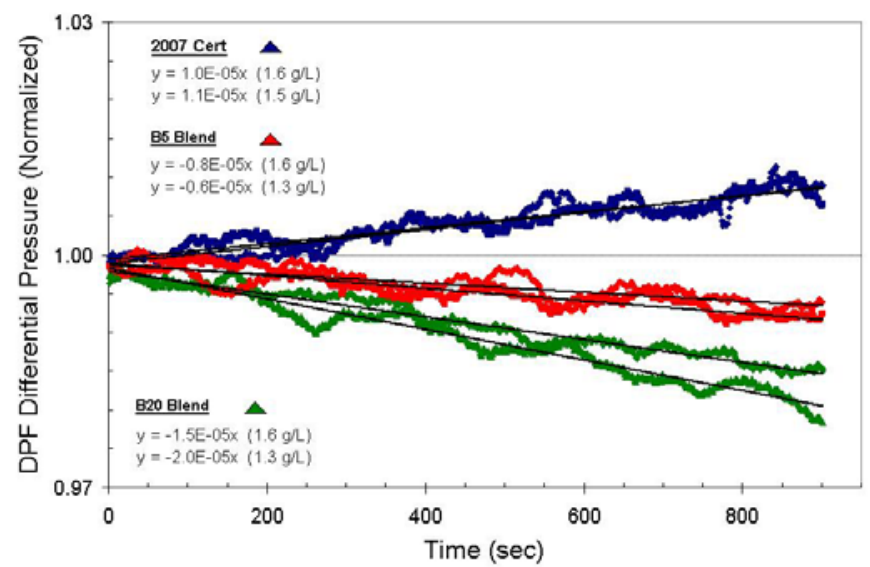

Figure 6. Regeneration rate test results for B20, B5 and 2007 Certification Diesel

\section{AVAILABILITY OF $\mathrm{NO}_{2}$ FOR DPF REGENERATION}

Catalyzed DPFs use $\mathrm{NO}_{2}$ as the oxidizer of trapped soot. Thus, increased $\mathrm{NO}_{x}$ from biodiesel blends could potentially be the cause of the observed higher regeneration rates. Table 2 shows brake specific $\mathrm{NO}_{x}$ levels at the regeneration condition for each fuel. For this experiment, differences in $\mathrm{NO}_{x}$ levels between 2007 certification diesel and the biodiesel blends are not statistically significant (at alpha $=0.05$ ). This suggests that differences in regeneration rates are not primarily due to differences in the availability of $\mathrm{NO}_{2}$ as a soot oxidizer, although higher $\mathrm{NO}_{2}$ availability may play a secondary role for B20.
Table 2. $\mathrm{NO}_{\mathrm{x}}$ Levels at Regeneration Condition of 1700 rpm and $250 \mathrm{ft}-\mathrm{lb}$ Torque ( $\mathrm{p}$-value for comparison of certification fuel $\mathrm{NO}_{\mathrm{x}}$ to biodiesel blend $\mathrm{NO}_{\mathrm{x}}$ )

\begin{tabular}{lccc}
\hline & 2007 Cert & B5 & B20 \\
\hline Run 1 $\mathrm{NO}_{x}(\mathrm{~g} / \mathrm{bhp}-\mathrm{hr})$ & 1.96 & 2.00 & 2.13 \\
Run 2 $\mathrm{NO}_{x}(\mathrm{~g} / \mathrm{bhp}-\mathrm{hr})$ & 2.06 & 1.93 & 2.16 \\
\hline Average $\mathrm{NO}_{\mathbf{x}}$ & $\mathbf{2 . 0 1}$ & $\mathbf{1 . 9 7}$ & $\mathbf{2 . 1 5}$ \\
\hline p-value & -- & $\mathbf{0 . 4 4 5}$ & $\mathbf{0 . 0 7 8}$ \\
\hline
\end{tabular}

The availability of $\mathrm{NO}_{\mathrm{x}}$ at each step in the balance point temperature test is illustrated in Figure 7 for each of the three test fuels. B100 NO levels (g/bhp-hr) trend higher at temperatures above $280^{\circ} \mathrm{C}$. However, at the balance point temperature for $\mathrm{B} 100\left(250^{\circ} \mathrm{C}\right)$, the availability of NOx is approximately the same as petroleum based diesel or $\mathrm{B20}$. The same is true for $\mathrm{NO}_{\mathrm{x}}$ levels at the $\mathrm{BPT}$ for $\mathrm{B} 20\left(317^{\circ} \mathrm{C}\right)$, once again indicating that reactivity of the soot, rather than availability of $\mathrm{NO}_{2}$, is the primary factor in the determination of the balance point temperature for each test fuel. It should be noted that speciation of $\mathrm{NOx}$ for $\mathrm{NO}$ and $\mathrm{NO}_{2}$ components was not performed. Biodiesel blends could also impact the $\mathrm{NO} / \mathrm{NO}_{2}$ split, which may have an impact on efficiency of the DPF. Also of note is the relative difference in the NOx/PM ratio for each test fuel. Because of lower engine out PM for biodiesel and the higher soluble organic fraction, the biodiesel NOx/Soot ratio will be much higher than that of 2007 certification fuel. The impact of this ratio on balance point temperature and regeneration rate was not explored in this study.

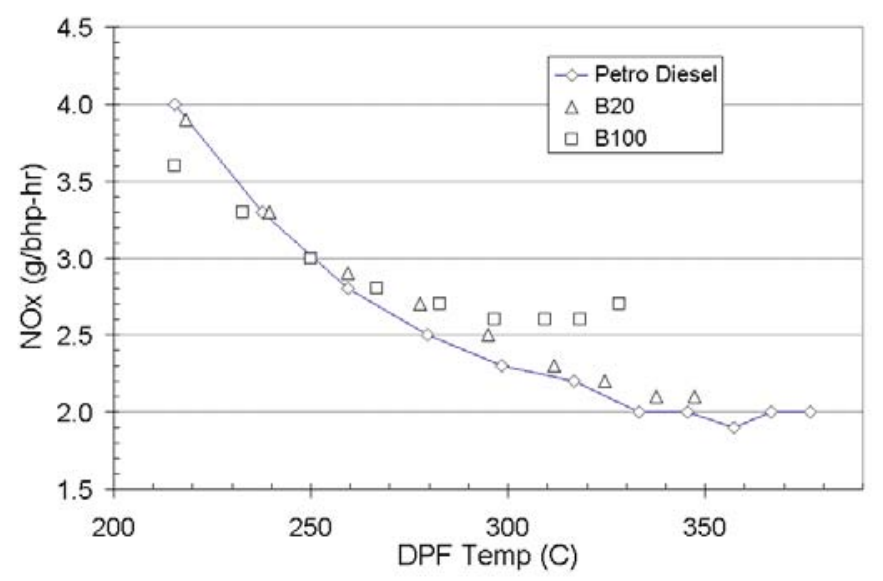

Figure 7. NOx levels at BPT steps for 2007 Certification Diesel, B20 and B100

\section{TRANSIENT EMISSIONS TESTING}

Baseline emissions over multiple hot start heavy-duty transient tests were measured for the 2007 certification fuel and a B20 blend. These tests were conducted with and without the DPF for both fuels to confirm operation of the filter and to determine reduction efficiencies of all regulated pollutants. Individual test results for each repeated run are shown in Table A-2. Table 3 shows the 
percent changes in emissions and fuel economy for each test configuration.

Table 3. Percent change in emissions and fuel economy ( $\mathrm{nd}=$ non-detectable differences with $95 \%$ confidence)

\begin{tabular}{lccccc}
\hline & PM & THC & CO & NOx & BSFC \\
\hline $\begin{array}{l}\text { Cert w/ DPF vs } \\
\text { Cert w/o DPF }\end{array}$ & $-99 \%$ & $-99 \%$ & $-97 \%$ & nd & $+1 \%$ \\
\hline $\begin{array}{l}\text { B20 w/ DPF vs } \\
\text { B20 w/o DPF }\end{array}$ & $-99 \%$ & $-99 \%$ & $-98 \%$ & nd & $+1 \%$ \\
\hline $\begin{array}{l}\text { Cert vs B20 w/o } \\
\text { DPF }\end{array}$ & $-24 \%$ & $-50 \%$ & $-22 \%$ & $+4 \%$ & $+3 \%$ \\
\hline $\begin{array}{l}\text { Cert vs B20 w/ } \\
\text { DPF }\end{array}$ & $-27 \%$ & $-74 \%$ & nd & $+4 \%$ & $+3 \%$ \\
\hline
\end{tabular}

Before installation of the DPF, the B20 blend achieved a $24 \%$ PM reduction relative to 2007 Cert, as shown in Figure 8. Following DPF installation, PM emissions were reduced by $90 \%$ for 2007 Cert and B20. B20 combined with the DPF still showed a statistically significant $(p<0.05)$ reduction in $\mathrm{PM}$ of $27 \%$ relative to 2007 Cert with DPF.

Without the DPF, biodiesel reduced emissions of both THC and CO by $50 \%$ and $22 \%$. In the case of both fuels the catalyzed DPF reduced THC and $\mathrm{CO}$ emissions by $97 \%$ to $99 \%$, to almost undetectable levels. $\mathrm{NO}_{\mathrm{x}}$ emissions increased for the biodiesel blend by $4 \%$ on average without the DPF compared to ULSD runs. DPF installation caused $\mathrm{NO}_{\mathrm{x}}$ emissions to increase by $1 \%$.

The biodiesel blend produced a 3\% $(p<0.001)$ increase in brake specific fuel consumption, consistent with the lower energy content of biodiesel, as shown in Table A-1. Installation of the DPF produced a $1 \%$ fuel economy penalty for both fuels $(p<0.001)$.

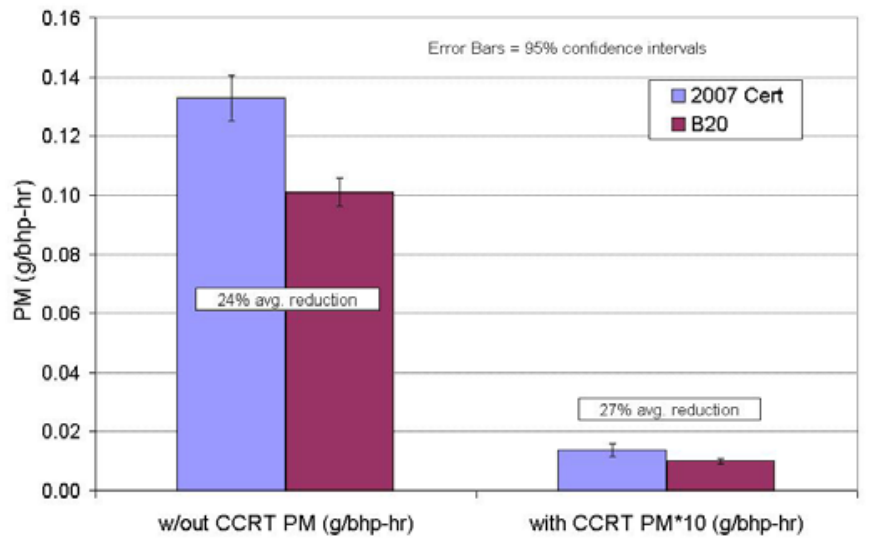

Figure 8. Transient test particulate matter emissions

\section{SOOT CHARACTERIZATION RESULTS}

\section{Soot Collection Methods}

Particle samples used for soot characterization were collected at the engine preload condition $(2000 \mathrm{rpm} 20 \mathrm{ft}-$ Ibs) for each test fuel. Without the DPF installed, dilute exhaust PM samples were collected onto $47 \mathrm{~mm}$ filters using methods consistent with CFR Title 40 Part 86 Subpart N. A butterfly valve was used to simulate exhaust back pressures similar to those created by the DPF. Approximately $46 \mathrm{mg}$ were collected onto Pallflex Quartz filters and $10 \mathrm{mg}$ were collected onto Teflon membrane filters. Bulk soot was collected directly from a preloaded DPF by back-flushing the filter with high pressure air into a collection canister. The DPF was first loaded by operating the engine at the preload condition for the time appropriate to achieve the $1.5 \mathrm{~g} / \mathrm{L}$ loading. Using this method, approximately 1 gram was collected for 2007 certification diesel and B100.

\section{Fuel and Lubricant Fraction of SOF}

The soluble organic fraction (SOF) of PM samples was extracted using supercritical $\mathrm{CO}_{2}$. The extracted hydrocarbon was delivered into an ODS trap (Agilent) and rinsed with $\mathrm{CS}_{2}$. The $\mathrm{CS}_{2}$ solution was injected into a gas chromatograph (HP 5880A) using a packed column (Chromosorb PAW) and a flame ionization detector (FID). The carrier gas was $\mathrm{N}_{2}$ and the heating rate is set at $10^{\circ} \mathrm{C} / \mathrm{min}$ for the temperature range from $35^{\circ} \mathrm{C}$ to $350^{\circ} \mathrm{C}$. The SOF elutes as two major bands corresponding to fuel at roughly 12 minutes and lubricant as a broad band centered around 17 minutes. The fuel light end components, normally eluting before 10 minutes in the chromatogram, are missing for all samples studied, suggesting that the light portion of the fuel has evaporated. Based on the ratio of the fuel and oil peak areas, we can determine the lubricant fraction in the SOF and the data are shown in Table 4.

PM samples collected on both quartz and Teflon membrane filters were examined for 2007 certification diesel, B20 and B100. For 2007 Cert the major SOF component is lubricant regardless of the filter type. When biodiesel is used, roughly $25 \%$ of the SOF can be attributed to the fuel. The contribution of the fuel is even larger when Teflon membrane filters are used.

Table 4. Lubricant Fraction of the PM Soluble Organic Fraction (SOF) Measured by GC

\section{Filter Type/Fuel Quartz Teflon Membrane}

\begin{tabular}{rrr}
\hline 2007 Cert & $95 \%$ & $96 \%$ \\
\hline B20 & $71 \%$ & $78 \%$ \\
\hline B100 & $75 \%$ & $50 \%$ \\
\hline
\end{tabular}

Organic Carbon/Elemental Carbon Ratio

The ratio of organic and elemental carbon was measured by a thermal-optical carbon aerosol analyzer. The PM sample is placed in a quartz oven and is heated under helium with a stepped temperature ramp up to $900^{\circ} \mathrm{C}$. Under this condition, all organic compounds are desorbed, pyrolyzed, and converted into $\mathrm{CO}_{2}$. The $\mathrm{CO}_{2}$ is swept through a heated nickel catalyst and converted into methane which can be quantified with a flame ionization detector. After the initial temperature ramp for 
organic carbon measurement, the oven is cooled to $600^{\circ} \mathrm{C}$ and the flow is switched to a helium/oxygen. A second temperature ramp is then initiated in the oxidizing gas stream to oxidize the elemental carbon. The elemental carbon is quantified in the same manner as the organic carbon. The elemental carbon can be also quantified by optical absorption detection.

As shown in Table 5, the OC/EC ratio follows a general trend of $\mathrm{B} 100>\mathrm{B} 20>2007$ Cert. This indicates that the PM generated by biodiesel contains more organic carbon and that organic carbon content is higher with increasing biodiesel content.

Table 5. OC/EC Ratio of Various PM Samples

\begin{tabular}{cccc}
\hline Fuel & $\begin{array}{c}\text { OC } \\
\boldsymbol{\mu g} / \mathbf{c m}^{2}\end{array}$ & $\begin{array}{c}\text { EC } \\
\boldsymbol{\mu g} / \mathbf{c m}^{2}\end{array}$ & OC/EC \\
\hline 2007 Cert & 206.37 & 38.11 & 5.42 \\
\hline 2007 Cert & 219.07 & 31.79 & 6.89 \\
\hline B20 & 419.94 & 17.63 & 23.82 \\
\hline B100 & 414.54 & 15.25 & 27.19 \\
\hline
\end{tabular}

\section{$\underline{\text { Raman Spectroscopy }}$}

Raman spectroscopy is unique in characterizing the long range interactions and the order-disorder effects in carbonaceous materials. Pristine graphite crystals only show two bands in first-order Raman spectrum, at 42 and $1578 \mathrm{~cm}^{-1}$. The $1578 \mathrm{~cm}^{-1}$ band is referred to as the graphitic band or G-band. As the graphite crystal is ground to destroy the ordering, a second band, referred as the amorphous band or disordered band, or D-band, begins to appear around $1340 \mathrm{~cm}^{-1}$. For carbonaceous materials such as soot or coal, the D-band is relatively broad and sensitive to the ordering of the carbon structure. Both maturation and oxidation level of PM affect the ordering of the carbon structure. The maturation, in morphological sense, is the collapse of small aromatic domains with 1 4 rings into a configuration containing larger ring number domains. Besides the growth of a two-dimensional domain size, the layer-to-layer orientation also plays a determining role for long range ordering $[9,10]$.

Two micro-Raman units were used to examine the soot samples: a Dilor XY800 Raman microprobe equipped with $\mathrm{Ar}^{+}$laser $(514.5 \mathrm{~nm})$ and a Rennishaw with a He-Ne laser $(632.8 \mathrm{~nm})$. Both laser wavelengths were focused on the sample through a microscope with a $50 x$ or $100 x$ objective lens and the scattered light collected through a holographic filter and detected via a CCD detector.

Figure 9 shows a comparison of Raman spectra of PM samples generated from 2007 certification diesel, B20 and $\mathrm{B} 100$. The graphite-like G-band is located around $1586 \mathrm{~cm}^{-1}$ with a bandwidth of about $100 \mathrm{~cm}^{-1}$. The disordered D-band is located around $1349 \mathrm{~cm}^{-1}$ with a much wider bandwidth $>250 \mathrm{~cm}^{-1}$. Multiple Raman spectra were taken for each sample at various locations to avoid inhomogeneity in the samples. The average ratio $G / D$ and the corresponding standard deviation are listed in Table 6.

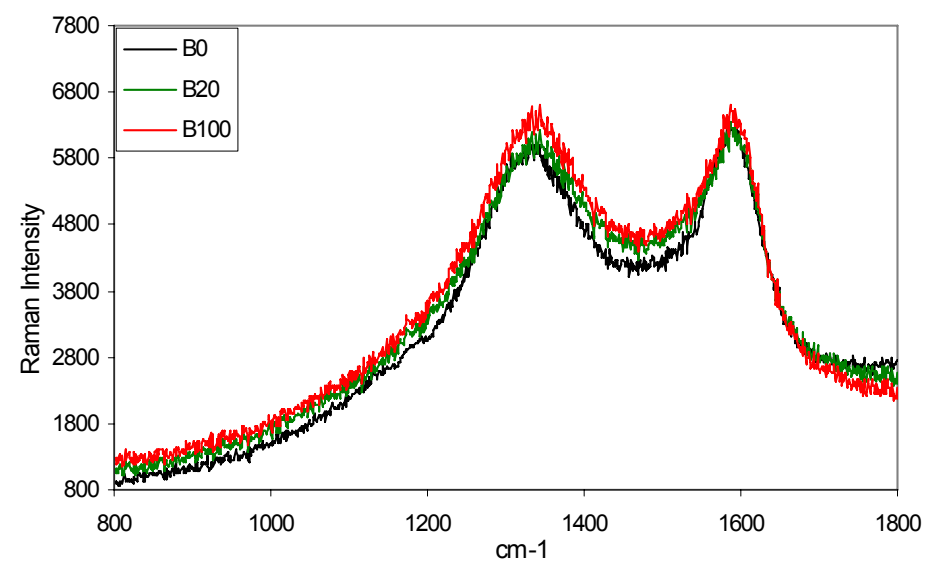

Figure 9. Raman spectra of the PM samples

As shown in Figure 10, the general trend for the $G / D$ ratio is to decrease with biodiesel blend level even though the standard deviation is suddenly increased for PM generated by B100, indicating much greater variation in domain structure. This is consistent with previously published data [7] showing much greater disorder for biodiesel soot. This trend is generally true regardless which Raman unit is being used. The slight ratio variation can be attributed to background difference caused by the different laser excitation wavelengths.

Table 6. G/D Ratio Measured by Rennishaw MicroRaman with $632.8 \mathrm{~nm}$ Excitation

\begin{tabular}{lcc}
\hline Fuel & G/D & $\begin{array}{c}\text { Standard } \\
\text { Deviation }\end{array}$ \\
\hline 2007 Cert (Quartz) & 0.836 & 0.057 \\
\hline B20 (Quartz) & 0.756 & 0.023 \\
\hline B100 (Quartz) & 0.586 & 0.175 \\
\hline 2007 Cert (Teflon) & 0.823 & 0.007 \\
\hline B20 (Teflon) & 0.836 & 0.026 \\
\hline B100 (Teflon) & 0.66 & 0.022 \\
\hline
\end{tabular}



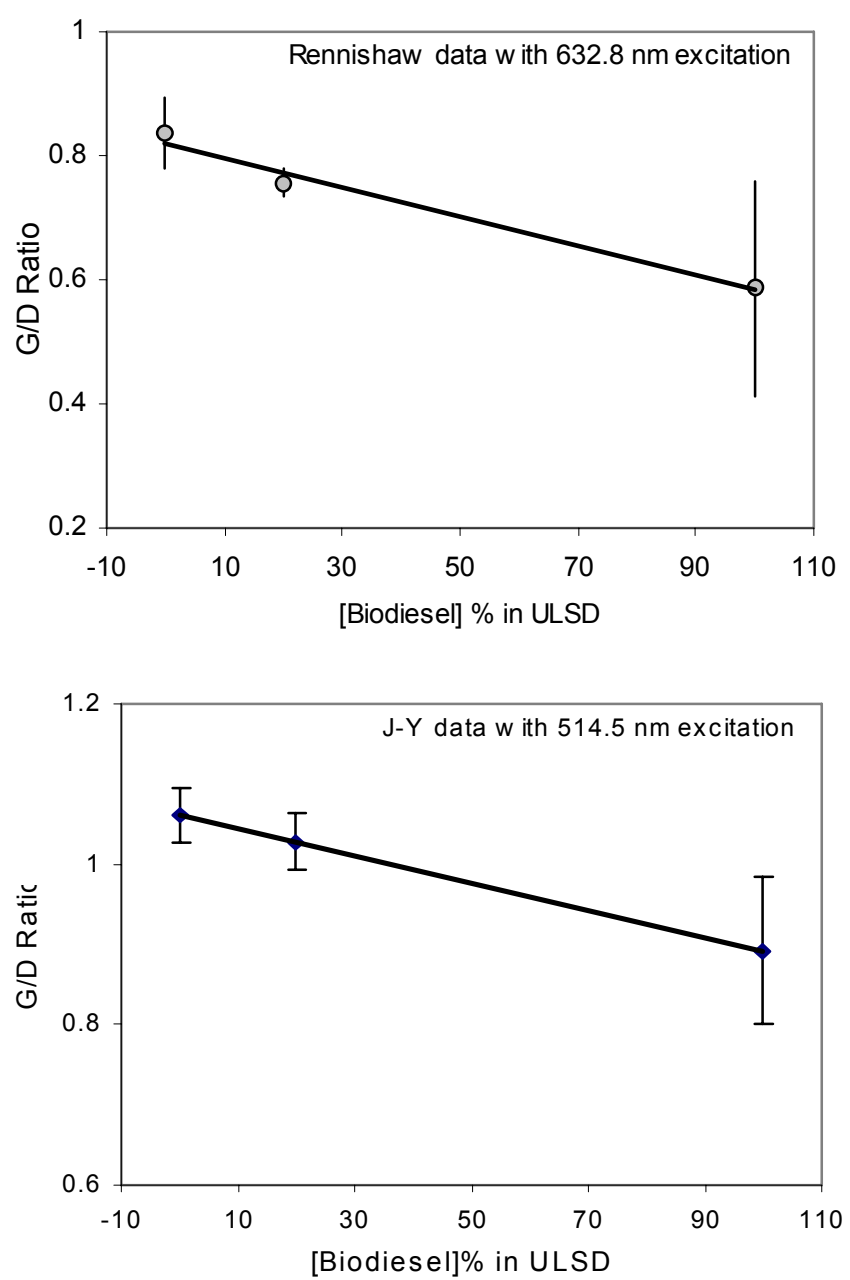

Figure 10. The dependence of the Raman G/D ratio on biodiesel blend level

\section{$\underline{\text { X-ray Spectroscopy }}$}

Energy-dispersive $\mathrm{x}$-ray spectroscopy (EDS) is based on measurement of the characteristic $x$-rays generated from a sample irradiated with high-energy electrons. EDS measurements were made with a Hitachi 4100 Field Emission scanning electron microscope with a Gresham Sirius EDS detector. The excitation voltage was $5 \mathrm{KV}$. Carbon to oxygen ratios determined for soot samples produced from 2007 certification diesel and from B100 were 25.34 and 20.34, respectively. This indicates that the B100 soot contains roughly $20 \%$ to $25 \%$ more oxygen than soot from 2007 certification diesel.

\section{Thermogravimetric Analysis}

Thermogravimetric measurement was performed with a Thermal Analysis TGA Q500 unit. All samples were originally collected on quartz filters. The sample was cut into small pieces stacked in the weighing pan. Thus, the majority of the sample weight is due to the quartz substrate. The heating rate was $100^{\circ} \mathrm{C} / \mathrm{min}$ for temperatures below $400^{\circ} \mathrm{C}$. The rate was decreased to $30^{\circ} \mathrm{C} / \mathrm{min}$ when temperature reached $400^{\circ} \mathrm{C}$ (at the location marked $\uparrow$ in Figure 11). At $400^{\circ} \mathrm{C}$, the purge gas was switched from $\mathrm{N}_{2}$ to $\mathrm{O}_{2}$. So at temperatures below $400^{\circ} \mathrm{C}$, we observed weight loss from evaporation and devolatilization, while above $400^{\circ} \mathrm{C}$ weight loss was caused by combustion.

Figure 11 compares TGA results for three PM samples from the different fuels. PM derived from B20 and B100 contains a much greater fraction that is volatile, consistent with the higher organic carbon content. Above $400^{\circ} \mathrm{C}$, there is a significant difference in the combustion temperature for these samples. For 2007 certification diesel, combustion occurs between about $650^{\circ} \mathrm{C}$ and $680^{\circ} \mathrm{C}$, while the temperature for $\mathrm{B} 20$ is shifted to $550^{\circ} \mathrm{C}-580^{\circ} \mathrm{C}$. The $\mathrm{B} 100$ sample shows a slightly higher conversion temperature, but the experiment was not precise enough to determine if there is a real difference between B20 and B100.

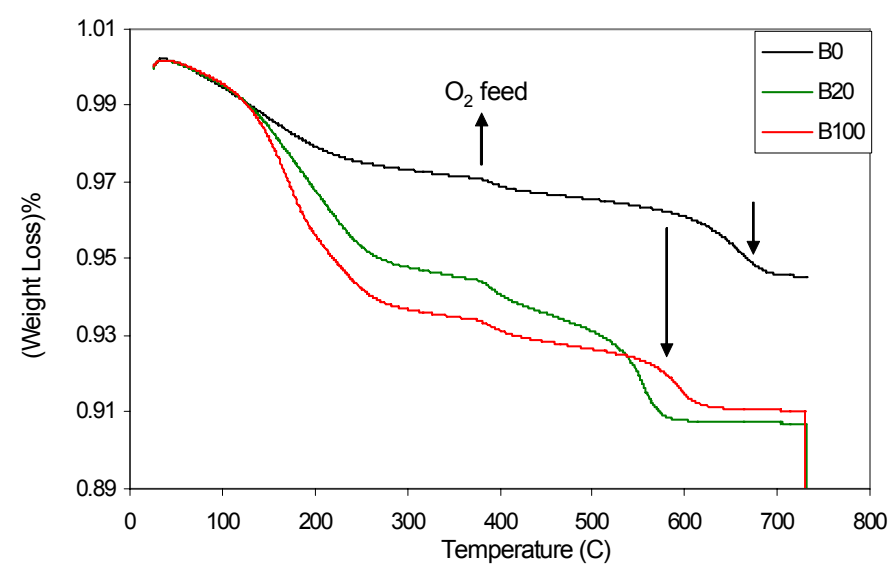

Figure 11. Thermogravimetric analysis results

\section{CONCLUSIONS AND RECOMENDATIONS}

Results show that on average, the balance point temperature is $45^{\circ} \mathrm{C}$ lower than 2007 certification diesel for B20 blends and more than $112^{\circ} \mathrm{C}$ lower for B100. Filter regeneration rate measurements indicate that biodiesel causes a measurable increase in regeneration rate, even at the $5 \%$ blending level. Transient emissions tests show a $24 \%$ particulate matter (PM) reduction for B20 without the DPF installed. Installation of the DPF caused PM emissions to drop by more than a factor of 10 for both fuels. Use of B20 with the DPF shows a statistically significant reduction of $27 \%$ below the petrodiesel+DPF level. The use of B20 caused a 3\% increase in fuel consumption, consistent with the lower energy content of this fuel. Installation of the DPF caused a $1 \%$ fuel economy penalty for both 2007 certification diesel and B20.

An examination of $\mathrm{NO}_{x}$ availability at the BPT and DPF regeneration conditions suggests that increased $\mathrm{NO}_{x}$ emissions from biodiesel and biodiesel blends are not responsible for the higher regeneration rate or lower BPT. Detailed chemical and spectroscopic characterization results point to the higher degree of disorder in the soot structure and higher oxygen content as the main factors responsible for the observed effects. This is confirmed by TGA combustion tests. The results 
of this study therefore confirm those of Boehman [7, 8] and indicate practical implications in terms of DPF regeneration and the potential for additional PM reduction.

The significant lowering of balance point temperature and increase in regeneration rate might allow passive DPFs to be used in lower temperature engine duty cycles, avoiding or reducing the need for actively regenerated filters and their associated fuel economy penalty. This hypothetical fuel economy benefit has yet to be demonstrated and will be the subject of future research.

\section{ACKNOWLEDGEMENTS}

This work was supported by the United States Department of Energy, FreedomCAR and Vehicle Technologies Program, the National Biodiesel Board, and by Cummins, Inc.

\section{REFERENCES}

1. Tyson, K.S.; Bozell, J.; Wallace, R.; Petersen, E.; Moens, L. Biomass Oil Analysis: Research Needs and Recommendations. NREL/TP-510-34796. Golden, CO: National Renewable Energy Laboratory, June 2004.

2. Sheehan, J.; Camobreco, V.; Duffield, J.; Graboski, M.; Shapouri, H. An Overview of Biodiesel and

Petroleum Diesel Life Cycles. NREL/TP-580-24772. Golden, CO: National Renewable Energy Laboratory, May 1998.

3. United States Environmental Protection Agency. A Comprehensive Analysis of Biodiesel Impacts on Exhaust Emissions. EPA420-P-02-001. Draft Technical Report. 2002.

4. McCormick, R.L., J.D. Ross, M.S. Graboski "Effect of Several Oxygenates on Regulated Emissions from Heavy-Duty Diesel Engines" Environ. Sci. Technol., Vol 31, 1997, p. 1144.

5. McCormick, R.L.; Tennant, C.; Hayes, R.R.; Black, S.; Williams, A.; Ireland, J.; McDaniel, T.; Frailey, M.; Sharp, C.A. Regulated Emissions from Biodiesel Tested in Heavy-Duty Engines Meeting 2004 Emission Standards. 2005-01-2200. Society of Automotive Engineers. 2005.

6. Frank, B.P.; Tang, S.; Lanni, T.; Rideout, G.; Beregszaszy, C.; Meyer, N.; Chatterjee, S.; Conway, R.; Lowell, D.; Bush, C.; Evans, J. A Study of the Effects of Fuel Type and Emission Control Systems on Regulated Gaseous Emissions from Heavy-Duty Diesel Engines. 2004-01-1085. Society of Automotive Engineers. 2004.

7. Boehman, A.L.; Song, J.; Alam, M. "Impact of Biodiesel Blending on Diesel Soot and the Regeneration of Particulate Filters" Energy \& Fuels. Vol 19, 2005, p. 1857.

8. Boehman, A.L. "Effect of Alternative Fuels on Soot Properties and Regeneration of Diesel Particulate Filters." 2005 Biodiesel Technical Workshop, November 2005, Denver Colorado.
9. Kelemen, S.; Fang, H.L. "Maturity Trends in Raman Spectra from Kerogen and Coal." Energy \& Fuels. Vol. 15, 2001, p. 653.

10. Fang, H.L.; Lance, M. Influence of Soot Surface Changes on DPF Regeneration. 2004-01-3043. Society of Automotive Engineers. 2004.

\section{ACRONYMS AND ABBREVIATIONS}

$\begin{array}{ll}\text { ASTM } & \text { American Society for Testing and Materials } \\ \text { BSFC } & \text { Brake specific fuel consumption } \\ \text { B100 } & 100 \% \text { biodiesel } \\ \text { B20 } & 20 \% \text { biodiesel, } 80 \% \text { petrodiesel } \\ \text { B5 } & 5 \% \text { biodiesel, } 95 \% \text { petrodiesel } \\ \text { CO } & \text { Carbon monoxide } \\ \mathrm{CO}_{2} & \text { Carbon dioxide } \\ \text { CVS } & \text { Constant volume sampling } \\ \text { DPF } & \text { Diesel particle filter } \\ \text { EC } & \text { Elemental carbon } \\ \text { EDS } & \text { Energy-dispersive x-ray spectroscopy } \\ \text { EPA } & \text { U.S. Environmental Protection Agency } \\ \text { FAME } & \text { fatty acid methyl esters } \\ \text { g/bhp-hr } & \text { grams per brake horsepower hour } \\ \text { NBB } & \text { National Biodiesel Board } \\ \text { NO } & \text { Oxides of nitrogen } \\ \text { NREL } & \text { National Renewable Energy Laboratory } \\ \text { OC } & \text { Organic carbon } \\ \text { ODS } & \text { Octadecylsilane } \\ \text { PM } & \text { Particulate matter } \\ \text { SOF } & \text { Soluble organic fraction } \\ \text { TGA } & \text { Thermogravimetric analysis } \\ \text { THC } & \text { Total hydrocarbon } \\ \text { ULSD } & \text { Ultra-low sulfur diesel (petrodiesel having } 15 \\ & \text { ppm or less sulfur) }\end{array}$


Table A-1. Fuel Properties

\begin{tabular}{|c|c|c|c|c|}
\hline Property & Method & Units & $\begin{array}{c}2007 \text { Certification } \\
\text { Diesel }\end{array}$ & $\begin{array}{l}\text { Neat Soy Biodiesel } \\
\text { (B100) }\end{array}$ \\
\hline Cetane Number & D613 & & 41 & -- \\
\hline Kinematic Viscosity 40C & D445 & $\mathrm{mm}^{2} / \mathrm{s}$ & 2.211 & 4.157 \\
\hline Cloud Point & D2500 & ${ }^{\circ} \mathrm{C}$ & -- & 1 \\
\hline Flash Point & D93 & ${ }^{\circ} \mathrm{C}$ & 78 & 152 \\
\hline Total Sulfur & D5453 & ppm & 9 & 6 \\
\hline Ash Content & D482 & $w t \%$ & $<0.001$ & -- \\
\hline Specific Gravity & D4052 & & 0.858 & -- \\
\hline Carbon Residue & D524 & $w t \%$ & 0.05 & 0.04 (neat sample) \\
\hline Corrosion, Copper strip & D130 & & 1B & $1 \mathrm{~B}$ \\
\hline Water and Sediment & D2709 & vol\% & 0.01 & 0.01 \\
\hline Carbon & D5291 & wt $\%$ & 87.27 & 77.38 \\
\hline Hydrogen & D5291 & wt\% & 13.04 & 11.86 \\
\hline Aromatics & D1319 & $\%$ vol & 28.2 & -- \\
\hline Distillation T90 & D86 & ${ }^{\circ} \mathrm{C}$ & 303 & -- \\
\hline Distillation T90 & D1160 & ${ }^{\circ} \mathrm{C}$ & -- & 359.6 \\
\hline Net Heat of Combustion & D240 & $\mathrm{MJ} / \mathrm{kg}$ & 42.6 & 37.3 \\
\hline Phosphorus & D4951 & ppm & -- & $<5$ \\
\hline Free Glycerin & D6584 & $w t \%$ & -- & 0.001 \\
\hline Total Glycerin & D6584 & wt \% & -- & 0.236 \\
\hline Acid Value & D664 & $\mathrm{mg} \mathrm{KOH} / \mathrm{g}$ & -- & 0.1 \\
\hline Sulfated Ash & D874 & $w t \%$ & -- & $<0.001$ \\
\hline
\end{tabular}


Table A-2. Heavy-Duty Transient Test Results (commercial ULSD)

\begin{tabular}{|c|c|c|c|c|c|c|}
\hline Fuel & Run \# & $\begin{array}{c}\mathrm{NO}_{\mathrm{x}} \\
\text { g/bhp-hr }\end{array}$ & $\begin{array}{c}\text { THC } \\
\text { g/bhp-hr }\end{array}$ & $\begin{array}{c}\text { CO } \\
\text { g/bhp-hr }\end{array}$ & $\begin{array}{c}\text { PM } \\
\text { g/bhp-hr }\end{array}$ & $\begin{array}{c}\text { BSFC } \\
\text { g/bhp-hr }\end{array}$ \\
\hline \multicolumn{7}{|c|}{ Without DPF: } \\
\hline 2007 Cert & 1347 & 2.09 & 0.185 & 1.53 & 0.1557 & 189.6 \\
\hline 2007 Cert & 1348 & 2.14 & 0.271 & 1.51 & 0.1434 & 189.9 \\
\hline 2007 Cert & 1349 & 2.18 & 0.226 & 1.56 & 0.1340 & 190.7 \\
\hline 2007 Cert & 1350 & 2.18 & 0.240 & 1.51 & 0.1141 & 190.3 \\
\hline 2007 Cert & 1351 & 2.19 & 0.247 & 1.53 & 0.1293 & 189.9 \\
\hline 2007 Cert & 1354 & 2.16 & 0.266 & 1.52 & 0.1228 & 189.7 \\
\hline 2007 Cert & 1355 & 2.17 & 0.281 & 1.54 & 0.1294 & 189.5 \\
\hline 2007 Cert & 1356 & 2.17 & 0.257 & 1.55 & 0.1345 & 189.1 \\
\hline 2007 Cert & 1357 & 2.17 & 0.281 & 1.51 & - & 188.8 \\
\hline Mean & & 2.16 & 0.250 & 1.53 & 0.1329 & 189.7 \\
\hline \multicolumn{2}{|c|}{ Standard Deviation } & 0.03 & 0.03 & 0.02 & 0.01 & 0.56 \\
\hline \multicolumn{2}{|c|}{ COV\% } & 1.4 & 12.3 & 1.2 & 9.5 & 0.3 \\
\hline B20 & 1359 & 2.19 & 0.111 & 1.23 & 0.1190 & 193.5 \\
\hline B20 & 1360 & 2.26 & 0.137 & 1.20 & 0.0918 & 195.0 \\
\hline B20 & 1361 & 2.28 & 0.126 & 1.19 & 0.0966 & 195.1 \\
\hline B20 & 1362 & 2.29 & 0.131 & 1.18 & 0.0960 & 195.4 \\
\hline \multicolumn{2}{|l|}{ Mean } & 2.26 & 0.126 & 1.20 & 0.1009 & 194.8 \\
\hline \multicolumn{2}{|c|}{ Standard Deviation } & 0.04 & 0.01 & 0.02 & 0.01 & 0.88 \\
\hline \multicolumn{2}{|c|}{ COV\% } & 2.0 & 9.1 & 2.0 & 12.2 & 0.5 \\
\hline \multicolumn{7}{|l|}{ With DPF: } \\
\hline 2007 Cert & 1309 & 2.14 & 0.004 & 0.03 & 0.0015 & 191.7 \\
\hline 2007 Cert & 1310 & 2.13 & 0.003 & 0.03 & 0.0013 & 190.4 \\
\hline 2007 Cert & 1311 & 2.15 & 0.001 & 0.04 & 0.0012 & 191.4 \\
\hline 2007 Cert & 1336 & 2.16 & 0.001 & 0.02 & 0.0022 & 191.8 \\
\hline 2007 Cert & 1317 & 2.16 & 0.001 & 0.06 & 0.0012 & 191.5 \\
\hline 2007 Cert & 1338 & 2.20 & 0.004 & 0.04 & 0.0012 & 191.9 \\
\hline 2007 Cert & 1339 & 2.18 & 0.003 & 0.06 & 0.0011 & 192.2 \\
\hline 2007 Cert & 1340 & 2.19 & 0.003 & 0.06 & 0.0010 & 191.9 \\
\hline 2007 Cert & 1341 & 2.19 & 0.003 & 0.06 & 0.0011 & 192.3 \\
\hline \multicolumn{2}{|c|}{ Mean } & 2.16 & 0.002 & 0.04 & 0.0014 & 191.6 \\
\hline \multicolumn{2}{|c|}{ Standard Deviation } & 0.03 & 0.00 & 0.02 & 0.00 & 0.52 \\
\hline \multicolumn{2}{|c|}{ COV\% } & 1.2 & 49.2 & 40.2 & 27.4 & 0.3 \\
\hline B20 & 1314 & 2.26 & -0.001 & 0.02 & 0.0009 & 194.1 \\
\hline B20 & 1315 & 2.27 & 0.000 & 0.03 & 0.0009 & 194.7 \\
\hline B20 & 1316 & 2.26 & -0.001 & 0.02 & 0.0009 & 192.9 \\
\hline B20 & 1328 & 2.24 & 0.004 & 0.02 & - & 205.8 \\
\hline B20 & 1329 & 2.28 & 0.000 & 0.04 & 0.0010 & 197.5 \\
\hline B20 & 1331 & 2.25 & 0.000 & 0.03 & 0.0012 & 196.7 \\
\hline B20 & 1332 & 2.25 & 0.000 & 0.03 & 0.0011 & 194.1 \\
\hline B20 & 1334 & 2.22 & 0.000 & 0.05 & 0.0009 & 196.2 \\
\hline \multicolumn{2}{|l|}{ Mean } & 2.25 & 0.001 & 0.03 & 0.0010 & 196.5 \\
\hline \multicolumn{2}{|c|}{ Standard Deviation } & 0.02 & 0.00 & 0.01 & 0.00 & 4.1 \\
\hline \multicolumn{2}{|c|}{ COV\% } & 0.8 & 360.0 & 32.3 & 10.7 & 2.1 \\
\hline
\end{tabular}

${ }^{a}$ Negative values indicate emissions below background levels.

b $1 \mathrm{~g} / \mathrm{bhp}-\mathrm{h}=1.341 \mathrm{~g} / \mathrm{kW}-\mathrm{h}$. 